\title{
Investigating Internal Accountability and Collective Capacity: Taking a Closer Look at Mathematics Instruction
}

\author{
Jori N. Hall \\ University of Georgia
}

\begin{abstract}
This case study uses multiple methods and gathers perspectives from administrators, teachers, and students to examine how a middle school develops internal accountability (Elmore, 2004) to address the needs of its diverse learners and external accountability mandates. Building on Newmann, King, and Rigdon's (1997) framework for collective capacity, the school's capacity to enact its internal accountability is explored. An in-depth investigation within the context of the school's mathematics program, focusing on the academic needs of low-income, African American learners is conducted to further explore collective capacity as primarily enacted vis-à-vis teachers' instructional strategies. The data presented contribute to a more complex and contextual perspective of teaching and learning within a high-stakes testing environment. The findings of this study show that despite tensions around student accountability and curricular demands, the school successfully incorporates internally-generated accountability and mandated strategies into their internal accountability system and demonstrates leadership capacity at multiple levels.
\end{abstract}

The No Child Left Behind (NCLB) (No Child Left Behind Act, 2001) policy represents external accountability which relies on external testing and sanctions to stimulate school improvement. But this accountability elicits varying responses among schools, particularly ones serving low-income and minority learners. While some schools thrive in a high-stakes testing environment, others respond by focusing on policy compliance and not the instructional needs of students (DeBray, Parson, \& Avila, 2003; Duffy, 2007). How, then, are some schools able to both respond to policy mandates while also meeting context-specific needs?

Research demonstrates that while all schools have their own internal accountability systems (Elmore, 2004), exponential teaching and learning improvement can come from developing collective coherence and alignment across four dimensions, that is, effective leadership, teachers' skills and knowledge, resources, and school autonomy (Newmann, King, \& Rigdon, 1997). To further elucidate the relationship between accountability and capacity, a case study approach was adopted for this study (Stake, 1995). Multiple methods were utilized to take the perspectives of teachers and administrators into consideration, and to gain insight into how a middle school serving diverse learners develops internal accountability, focusing on its collective capacity to enact the same. Collective capacity was further explored by examining the school's mathematics program. 


\section{Research on Internal Accountability and Collective Capacity}

Within the larger external accountability movement, individual schools with unique demographics function based on their histories and daily norms. These norms are primarily shaped by school members' notions about teaching and learning and influence the "variety of ways in which schools decide to whom they are accountable, for what, and how" (Elmore, 2004, p. 133); in other words, it constitutes an internal accountability system. Internal accountability includes a commitment to: (a) modify content and instruction, (b) monitor progress, and (c) institute rewards and sanctions (Boudett, City, \& Murnane, 2005; Carnoy, Elmore, \& Siskin, 2003; Elmore, 2004; Newmann et al., 1997; Rallis \& MacMullen, 2000).

Newmann et al. (1997) suggest that strong internal accountability reflects the capacity of a school to collectively organize the following four dimensions: (a) effective leadership, (b) teachers' professional knowledge and skills, (c) technical (i.e., curriculum materials, library) and financial resources, and (d) the autonomy to act according to the demands of local contexts. The author drew upon other empirical research that signaled the importance of Newmann et al.'s proposed capacity dimensions. A synthesis of school-level capacity research suggests the following. First, research suggests that effective leadership involves fostering meaningful interactions, knowing the skills and knowledge levels of others, and organizing these varying competencies in ways that address the teaching and learning goals of the school (Elmore, 2000; Spillane, 2005). Second, research related to teachers' professional knowledge and skills speaks to collaborative instructional practices among faculty, the capacity of faculty to use multiple data sources to inform instruction, and the quality of their professional development experiences (Boudett et al., 2005; Carnoy et al., 2003; Darling-Hammond, 2004; Desimone, Garet, Birman, Porter, \& Yoon, 2002; Harris, 2001; Newmann, King, \& Youngs, 2001; Supovitz, 2002). Third, studies suggest tha resources be directed after goals and a plan to accomplish them have been decided upon and made clear (Cohen, Raudenbush, \& Ball, 2003). Lastly, the autonomy to act in accordance to local contexts builds on findings that effective schools are schools with collaborative faculty involvement in school improvement initiatives, which, in turn, is thought to foster empowerment and the capacity to impact school improvement (Brown \& Cooper, 2000; Smylie, Lazarus, \& Brownlee-Conyers, 1996).

Akin to other capacity frameworks (Chaskin, 2001), the collective capacity framework moves toward a richer, more complex conceptual understanding of capacity. As articulated in this work, collective capacity represents an orientation with respect to how roles and responsibilities are shared, how resources are used, how the school is organized, and how autonomy is negotiated. Developing collective capacity is a challenging, time-intensive process (Desimone, 2002). However, when schools develop the collective capacity to align the aforementioned dimensions with their shared school mission for teaching and learning (see Appendix A), there is powerful potential to implement effective reform initiatives. 


\section{Understanding Collective Capacity within a Mathematics Program}

Examining collective capacity in a middle school mathematics program is imperative for several reasons. First, mathematics education has a long history of reform efforts designed to address students' opportunity to learn (Tate, 2005). These reforms have relied on revising textbooks (Remillard, 2005) and have emphasized rudimentary procedures. While these reforms have improved the low-level computational skills of some student sub-groups (Secada, 1992), the reforms have also resulted in a widening gap between different students' opportunities to learn (i.e., course options and cognitively demanding instruction), which have been linked to students' socioeconomic status, race, and gender (Lubienski, 2002; Resnick, 2006; Tate). Even with the recently published national mathematics standards (i.e., National Council of Teachers of Mathematics, 1989, 2000) and states' mathematics standards and standards-based mathematics curriculum materials (Remillard, 2005), differences and similarities within and between demographic groups remain inadequately understood and addressed.

Second, because less is known about middle school mathematics teachers and students, many researchers perceive middle school, and particularly middle school mathematics, as a critical gatekeeper to high school course options and college enrollment (Lubienski, 2002). Finally, the legacy of uneven mathematics instruction within the context of high-stakes accountability and rigorous standards signals the urgency of understanding how schools support quality mathematics curriculum and instruction.

\section{Methods}

\section{Case Description}

Negola Middle School (NMS), a psydonym, is situated within a small urban community in East Central Illinois and serves $700+$ sixth, seventh and eighth grade students. The majority of students at NMS (56\%) are White, while the rest are African American (38\%) or of other classifications (6\%). Twenty-five percent of the entire student bodies are low-income African Americans. Per NCLB requirements, NMS must administer the Illinois Standards Achievement Test (ISAT) to show the school's progress toward meeting state learning standards. When NCLB was initially implemented, ISAT test scores revealed underachievement, particularly in mathematics. However, NMS student performance history since then has shown improvement in the number of students meeting or exceeding state standards. Because NMS increased mathematics achievement, it was selected as an appropriate site to explore the internal accountability mechanisms and collective capacity practices needed to respond to the external accountability demands imposed by NCLB. 
The organizational structure of NMS is configured according to interdisciplinary teams of teachers from core disciplines (mathematics, science, social studies, and language arts/reading) who are responsible for the same students. Non-core subject teachers (e.g., music, art) support these teams. There are two teams per grade level and each team consists of approximately $110-125$ students. The mathematics courses include: Math I (grade-level content), co-taught Math I (grade level content taught with support from special education teachers), and Math II (honors, slightly above grade level) offered by the $6^{\text {th }}$ and $7^{\text {th }}$ grade level teams. Pre-Algebra, co-taught Pre-Algebra, and Algebra are the $8^{\text {th }}$ grade team's equivalent of grade-level, co-taught, and honors courses, respectively.

The NMS mathematics curriculum is aligned with the principles and standards of the National Council of Teachers of Mathematics (NCTM) published in 2000. The curriculum emphasizes inquiry-based instruction, including investigations of problems, conceptual understandings, and cooperative learning. To ensure content coverage and to address pedagogical issues, teachers typically worked with the district-level mathematics administrator and met as a content area team once a week led by the mathematics program head (the $8^{\text {th }}$ grade math teacher).

\section{Data Collection and Analysis}

Data was collected in two phases. During phase one, individual interviews with the principal, assistant principal, and dean of students were conducted in order to collect information related to how administrators perceived the school's internal accountability, including questions related to the school's leadership practices and its response to both NCLB and district mandates. (See Appendix B for administrator interview guide.) Field notes (Patton, 2002) from these semi-structured interviews were coded, allowing the author to organize data based on the internal accountability framework (i.e., modifying content and instruction, monitoring progress, and sanctions and rewards). The constant comparative method (Bogdan \& Biklen, 2003) was used to investigate consistencies and inconsistencies within and across aspects of the framework and to explore emergent trends. Relevant documents and informal observations were also analyzed with respect to the internal accountability aspects.

Questionnaire. Based on Newmann et al.'s (1997) proposed collective capacity framework, the author prepared a questionnaire to assess the collective capacity of the school (see Hall, 2008, for questionnaire development details). The final questionnaire used in this study (see Appendix $C$ ) includes the following collective capacity framework dimensions: (a) leadership, (b) instruction, (c) decision-making, and (d) resources. The questionnaire was distributed to all 54 faculty members during a faculty meeting in the fall of 2007. Survey respondents were asked to rate items on a 5-point agreement scale (strongly agree, agree, neither agree nor disagree, disagree, strongly disagree). Fortyfive questionnaires were completed (response rate $=83 \%$ ) by NMS teachers $(n=43)$ 
and administrators $(n=2)$. Descriptive statistics were then calculated from the questionnaire data.

During the second phase of the study, an in-depth investigation of collective capacity within the context of the school's mathematics program was conducted. Data collection included 40 direct observations and six individual interviews.

Observations. Direct observations included 14 from faculty meetings and 26 from the classrooms. To understand school level collective capacity with respect to teacher collaboration, decision-making, and leadership practices, as well as to learn how resources were used, scheduled faculty meetings (i.e., professional development meetings, mathematics team teachers' meetings, and school improvement meetings) were attended. (See Appendix D for meeting observation guide.) Each meeting lasted between 60 and 90 minutes. To capture and describe the ways in which collective capacity manifested in the classrooms, mathematics courses at each grade level were observed for approximately 40 minutes. These observations focused on teachers' collaborative practices such as co-teaching efforts, the general classroom climate, and teacher-student interactions. (See Appendix E for classroom observation guide.) Field notes were taken for each faculty meeting and mathematics class observation.

Faculty interviews. Individual interviews with mathematics teachers (i.e., the two teachers from the sixth, seventh, and eighth grades) were conducted to understand how they work collectively. Semi-structured interviews with mathematics teachers (conducted in phase two) and administrators (conducted in phase one) were guided by a protocol (see Appendix F) that posed similar open-ended questions and probes in order to have each respondent experience a common set of questions (Patton, 2002). Each respondent was both invited and volunteered to participate. Each interview was audio taped and lasted approximately 60 minutes.

Interview transcriptions and field notes from phase two were coded and analyzed in the same way as the data in phase one, but with the collective capacity framework in mind.

\section{Validity and Reliability}

In terms of the qualitative data, strategies of persistent observation, member checking, and an audit trail were employed to maximize the credibility and confirmability of the findings (Lincoln \& Guba, 1986). To develop the questionnaire and interpret the results, four strategies were used to address reliability and validity (Weiss, 1998). First, as mentioned previously, the collective capacity dimensions were defined by a literature review related to the capacity needed for school improvement. Second, to address the contextual relevance of the dimensions being measured (Kirkhart, 1995) preliminary observations and informal interviews were conducted. Third, to assess the intelligibility of the questions (Fowler, 2002), the questionnaire was reviewed by four leading educational researchers. Lastly, items were modified and deleted based on the results 
of a cognitive lab with middle school teachers (Fink, 2006) and an analysis of the pilot's technical characteristics (e.g., reliability analysis, descriptive statistics).

\section{Findings}

The data analysis procedure for this study revealed a description of the school's internal accountability system, faculty perceptions of collective capacity, successful capacity strategies, and internal accountability tensions. These findings demonstrate the complex inter-relationships among pressure for improvement, notions school members have about teaching and learning, teacher collaboration, and multilevel leadership capacity. Below is a summary of findings drawn from the study. (See Hall, 2008, for complete findings.)

\section{Internal Accountability}

The NMS internal accountability system addresses each aspect of the internal accountability framework (see Appendix G), integrates externally mandated as well as internally generated strategies. For example, NMS uses externally mandated state assessments and student disciplinary data (number of discipline referrals) as part of their internal accountability system to monitor progress. When asked about external mandates, administrators described the pressure from NCLB and district demands as having "big brother look over your shoulder" and experiencing the expectation to continuously "raise your game." The administrators further commented that the external requirements to collect and review multiple forms of data facilitates collaborative efforts and directs initiatives at the school, as evidenced by the following quotes:

Currently the [district] monitor asked us to provide quarterly updates on our progress in various areas. So it keeps the conversation around accountability high. And creates a mindset of collaboration around issues where success happens and when to celebrate, but also on issues where we still need to work harder to make strong gains. That's sort of the collaborative nature ... where data says we have to take a look. (Principal)

As a building, we put some systems in place to assist our teachers and students in meeting the [NCLB and district] requirements. (Assistant principal)

Because we're held to the gun basically - to keep our test scores high and make sure our students are doing well in their subject areas, and make sure our teachers are teaching what they are supposed to be teaching-we've implemented ... guidelines for every month, with the topics teachers should be teaching when it comes to testing. (Dean)

An additional aspect of internal accountability that was not part of the original framework was also revealed: the social curriculum. Influenced by both a review of 
disciplinary data that revealed an overwhelming number of discipline referrals and the external pressure to increase academic achievement among sub-groups, NMS implemented a school-wide program called Nurtured Heart (Grove \& Glasser, 2007). This program is an internally-initiated accountability strategy that aims to promote a positive learning environment and to reduce the number of student detentions. Other social curriculum programs target students facing challenges in meeting school expectations through adult mentoring and academic tutoring.

\section{Connecting Accountability and Capacity}

As previously noted, connected to a school's internal accountability system is its collective capacity to carry out the same. Administrators spoke about their ability as a leadership team to work collaboratively with each other, to support members of the school community, and to provide a vision for school goals, all imperative for a strong internal accountability system (Elmore, 2003).

The leadership is cohesive amongst the key administrators in our vision and goals for our school. We have a common vision ... a high sense of energy and focus around those goals. The leadership is very collaborative in our work. ... We create an environment, a school community where students, teachers, and parents want to be because they are respected. Whatever their assigned task, they feel they are supported by the administration. (Principal)

I think part of that [leadership team] planning is to provide teachers with the vision and here's what I'm going to do to help you to get there. (Assistant principal)

I think the leadership team is . . very cohesive. We are the type of leaders who encourage our staff-very much so. We convey what we want them [teachers] to do. (Dean)

Questionnaire results also affirmed the positive perceptions of leadership capacity that had been revealed in interviews with administrators, with a mean of 4.1 , on a scale ranging from 1 to 5 . In particular, NMS administrators (i.e., principal, assistant principal, dean of students) were perceived as having the collective capacity to collaborate with faculty and staff, distribute leadership tasks among faculty, foster a collective vision, and work collaboratively toward shared teaching and learning goals. NMS faculty also viewed themselves as having relatively high instructional collective capacity, which is consistent with their internal accountability goal, to modify content and instruction, with a mean of 4.3. In general, the questionnaire results showed that NMS faculty reported overall positive perceptions of its collective capacity, with means ranging from 3.7 to 4.3. Yet, while the questionnaire results provided school-level perceptions related to collective capacity, they offered little on classroom-level insight. 


\section{Successful Capacity Strategies}

Investigating the mathematics program revealed positive features related to its collective capacity, especially in the areas of leadership, resources, and decisionmaking. Because mathematics teachers had a shared commitment to fostering a positive school environment, collective capacity around the social curriculum is also discussed.

Leadership. Interviews and observations from the mathematics program further affirmed the collective capacity of school-level administrators revealed in the questionnaire results. In addition, evidence emerged from the mathematics teachers that allowed the expansion of the term "leadership" to include teacher leadership (the mathematics program head) and district leadership (the mathematics coordinator).

Administration is very important. They come and they support what I'm doing. ( $8^{\text {th }}$ grade mathematics teacher)

[O]ur math program head... always provides support...for new materials she got me ISAT books and things like that. ( $6^{\text {th }}$ grade mathematics teacher)

[O]ur district [coordinator] is awesome...she adjusts to things that we want to talk about. We have a say about when we want to get things done. $\left(6^{\text {th }}\right.$ grade mathematics teacher)

The collective leadership capacity practices at the school, program, and district levels were critical to the support of the school's internal accountability system because these practices focused on (a) distributing leadership expertise and fostering meaningful interactions, (b) enhancing the skills and knowledge of the mathematics teachers, and (c) utilizing input from the team to make decisions.

Resources and decision making. The decision making autonomy to determine the use of funding resources was also reported and observed. For example, during an observation of a mathematics team meeting, the author witnessed mathematics teachers making decisions about how money from school fundraising would be used for instruction. Together, teachers discussed the advantages and disadvantages of possible purchases. These practices enhanced their capacity to work collectively and to determine agreed upon budget items. Moreover, within content team meetings, NMS teachers were able to experience mutually supportive relationships (Hawley-Miles \& Darling-Hammond, 1998; Newmann, 1996) and, consequently, the collective capacity needed to focus on students' needs, as evidenced by the following quotes:

The [mathematics] team is very important because we get to come together and talk. We can say, "Oh if they [students] are having problems in this and this, 
these are things that worked, these are things that haven't worked." $\left(7^{\text {th }}\right.$ grade mathematics teacher)

Just to be able to bounce ideas off of each other is probably something that is pretty unique in terms of working that closely with each other. $\left(6^{\text {th }}\right.$ grade mathematics teacher)

Social curriculum. The author observed teachers advancing the social curriculum through the Nurtured Heart approach. For example, teachers commonly said, "Thank you for listening" and, "Please reset" to redirect disruptive or inattentive students. However, a larger part of creating a positive environment had to do with teachers' perceptions about students' abilities to do the work. Classroom observations revealed some positive beliefs among teachers about students' mathematics abilities. The following quotes demonstrate the notions teachers had about the relationships between students' abilities and factors such as the students' home environment, peer influence, self-confidence and motivation that mediate students' academic success.

It's not so much their [students'] capabilities in terms of what they are able to do for their academics as it is just what's going on at home or what's going on with ... their peers. But if they have something that they can go to that will support them, then they will feel more motivated to get their homework done and come and be prepared. A lot of times students ... just lack motivation and selfconfidence to do well. So building in that self-confidence piece for them, I have seen a great change. $\left(6^{\text {th }}\right.$ grade mathematics teacher)

Honestly the problem is not learning the material, it's motivation ... we'll say a little more positive things. We will try and get them to have self-confidence and believe that they can do it. ( $7^{\text {th }}$ grade mathematics teacher)

Building confidence is important ... I have heard students say, "It wouldn't matter if I tried." But I say to them they can do it, they believe that . . . then they start following that path. $\left(6^{\text {th }}\right.$ grade mathematics teacher, 2$)$

On the whole, teachers seem to have a unified understanding about providing positive reinforcement and the factors that impact student learning, notably motivation. NMS mathematics teachers believe, to some extent, that they have some capacity to build students' self-confidence. This finding speaks to the teachers' perceived efficacy, or the belief a teacher has about his or her capacity to affect student performance (Tschannen-Moran, Woolfolk, Hoy, \& Hoy, 1998). 


\section{Internal Accountability Tensions}

Despite teachers perceived efficacy, tensions related both to modifying content and instruction and to monitoring progress were repeatedly reported by mathematics teachers and observed in their classrooms.

Modifying content and instruction. Despite the relatively high collective instructional capacity questionnaire results, the collective capacity to modify content and instruction was slightly undercut due to inadequate time to meet the demands of the district-mandated curriculum pacing guide. The tension between the guide and modifying instruction to meet students' needs is illustrated by the following quote:

And so it [the curriculum] is very much driven to meet this timeline it can't necessarily give you the freedom to sort of take those times where you need to take a step back and slow down. $\left(6^{\text {th }}\right.$ grade mathematics teacher)

Additionally, the curriculum is intended for class periods that extend for 50-60 minutes. But at NMS, each class period lasts 43 minutes. An $8^{\text {th }}$ grade teacher expressed the general view among mathematics teachers in relation to this particular instructional tension:

I don't know if it [the mathematics curriculum] works really well for the time we have. In order to do the Launch and Explore [an investigative math activity], you don't really have time for all of that.

Monitoring students' progress. As mentioned previously, NMS is required to collect and review data from multiple sources. Yet, observations of mathematics classrooms and interviews revealed that some teachers privilege students' benchmark and state assessment scores when monitoring students' progress. In contrast, other teachers view monitoring progress in light of students' background and other indicators of growth in addition to mandated assessments, as illustrated by the following quotes:

... the district quarterlies, and the students having to take extended responses with it, ... I'm just monitoring how my kids do according to that. $\left(6^{\text {th }}\right.$ grade mathematics teacher)

We consider the individual's home life and the family's socioeconomic status. We decide on an individual basis what students need. This carries into the classroom. $\left(8^{\text {th }}\right.$ grade mathematics teacher $)$

I not only consider testing, but the honor roll and everything else. $\left(7^{\text {th }}\right.$ mathematics teacher) 
While the NMS organizational structure provided time for collaboration, this study observes that the tensions related to limited time to modify content and instruction hampered mathematics teachers' overall collective instructional capacity to teach the curriculum the way in which it was intended. The contradictory notions related to monitoring students' progress were not surprising considering teachers are judged by NCLB for their ability as a school to meet or exceed AYP goals, particularly with respect to student sub-groups.

\section{Discussion}

Results from this study demonstrate how external accountability pressure has led to increased attention on the use of externally mandated data to monitor the school's progress and led to an internal accountability system that incorporates internallyinitiated strategies. These findings bear out the claims of some accountability researchers who suggest there are some positive effects of external accountability (Fusarelli, 2004; Roderick, Jacob, \& Bryk, 2002). Further, the findings of this study suggest that teachers implement the social curriculum, through positive reinforcement, and to some extent, that it is promoting a positive school environment. Research has advocated the idea that reinforcing positive behaviors will help teachers to build nurturing relationships and to invite increased participation and responsibility among students (Noddings, 2006). Moreover, the findings presented in this study related to the belief a teacher has about his or her capacity to affect student performance are important because mathematics teachers' beliefs about students shape the character of classroom experiences (Desimone, 2002; Martin, 2007; Spillane, 2005).

At the same time, external accountability can also generate some accountability tensions that impact collective capacity. Evidence from the mathematics program highlights tensions around meeting curricular demands and privileging test scores as a primary strategy to monitor students' progress. These findings are important as they both have major implications for collaborative instructional practices among faculty. Research has shown that these practices tend to undermine pedagogical creativity, narrow teacher education, and limit student learning opportunities (Casey, 2007; Goertz \& Massell, 2005; Roderick, et al., 2002; Sleeter, 2008). Furthermore, as previously mentioned, the way in which schools privilege test outcomes can potentially position them to focus more on external mandate compliance rather than the academic needs of students (DeBray et al., 2003).

This study also highlights two key facilitators of collective capacity: (a) teacher collaboration and (b) leadership practices at multiple levels. Content team meetings highlight the importance of school structures that allow teachers to collaborate with peers. On these occasions, teachers were given opportunities to reflect collectively on previous lessons, and share instructional materials and practices, all important to enhancing instructional capacity. This study demonstrates that a common time to meet fosters a supportive professional culture (Newmann et al., 1997). 
Lastly, the study also led to an enhanced understanding of the importance of three levels of leadership (i.e., school, program, and district levels) to support the overall collective capacity of a school (Duffy, 2007). The results of this study demonstrate that school-level administrators are most essential to setting the vision and goals of the school; the program head is most critical in providing teachers with the level of contact needed to support the timely modification of instructional strategies; and the district coordinator is most influential in providing increased opportunities for active learning and other needed resources. These three levels of leadership complement the needs of middle school teachers by providing a balance of guidance and autonomy. The ways in which the levels of leadership in this case function reinforce the research claim of Spillane, Halverson, and Diamond (2001), who suggest that leadership is "often distributed among multiple leaders" (p. 25).

\section{References}

Bogdan, R. C., \& Biklen, S. K. (2003). Qualitative research for education: An introduction to theory and methods. Boston: Allyn \& Bacon.

Boudett, K. P., City, E., \& Murnane, R. (Eds.). (2005). Data wise: A step-by-step guide to using assessment results to improve teaching and learning. Cambridge, MA: Harvard Publishing Group.

Brown, B. R., \& Cooper, G. R. (2000, May). School-based management: How effective is it? NASSP Bulletin, No. 616, 77-85.

Carnoy, M., Elmore, R., \& Siskin, L. (2003). The new accountability: High school and high-stakes testing. New York: Routledge.

Casey, H. (2007). Making room for the middle grades: High-stakes teaching in an era of high-stakes testing, Journal of Curriculum and Instruction, 1(1), 14-30.

Chaskin, R. (2001). Building community capacity. A definitional framework and case studies from a comprehensive community initiative. Urban Affairs Review, 36(3), 291-323.

Cohen, D., Raudenbush, S., \& Ball, D. (2003). Resources, instruction, and research. Educational Evaluation and Policy Analysis, 25(2), 1-24.

Darling-Hammond, L. (2004). Standards, accountability and school reform. Teachers College Record, 106(6), 1047-1085. 
DeBray, E., Parson, G., \& Avila, S. (2003). Internal alignment and external pressure: High school responses in four state contexts. In M. Carnoy, R. Elmore, \& L. Siskin (Eds.), The new accountability: High schools and high stakes testing (pp. 55-85). New York: Teachers College Press.

Desimone, L. (2002). How can comprehensive school reform models be successfully implemented? Review of Educational Research, 72(3), 433-479.

Desimone, L., Garet, M., Birman, B., Porter, A., \& Yoon, K. (2002). How do district management and implementation strategies relate to the quality of the professional development that districts provide to teachers? Teachers College Record, 104(7), 1265-1312.

Duffy, G. (2007). Thriving in a high-stakes testing environment. Journal of Curriculum and Instruction, 1(1), 7-13.

Elmore, R. (2000). Building a new structure for school leadership. Washington, DC: The Albert Shanker Institute.

Elmore, R. (2003). Accountability and capacity. In M. Carnoy, R. Elmore, \& L. Siskin (Eds.), The new accountability: High schools and high-stakes testing. New York: Routedge.

Elmore, R. (2004). School reform from the inside out: Policy, practice, and performance. Cambridge, MA: Harvard Education Press.

Fink, A. (2006). How to conduct surveys: A step-by-step guide. Thousand Oaks, CA: Sage Publications.

Fowler, F. J. (2002). Survey research methods ( $3^{\text {rd }}$ ed.). Thousand Oaks, CA: Sage Publications.

Fusarelli, L. D. (2004). The potential impact of the No Child Left Behind Act on equity and diversity in American education. Educational Policy, 18(1), 71-94.

Goertz, M., \& Massell, D. (2005, January). Holding high hopes: How high schools respond to state accountability policies (No. RB-42). Philadelphia: Consortium for Policy Research in Education.

Grove, T., \& Glasser, H. (2007). The inner wealth initiative: The nurtured heart approach for educators. Tucson, AZ: Nurtured Heart Publications.

Hall, J. (2008). Educational accountability: Investigating the collective capacity of a middle school (Doctoral dissertation). Available from ProQuest Dissertations and Theses database. (AAT No. 3314784) 
Harris, A. (2001). Building the capacity for school improvement. School Leadership and Management, 21(3), 261-270.

Hawley-Miles, K., \& Darling-Hammond, L. (1998). Rethinking the allocation of teaching resources: Some lessons from high performing schools. Educational Evaluation and Policy Analysis, 20(1), 9-29.

Kirkhart, K. E. (1995). Seeking multicultural validity: A postcard from the road. Evaluation Practice, 16(1), 1-12.

Lincoln, Y. S., \& Guba, E. G. (1986). But is it rigorous? Trustworthiness and authenticity in naturalistic evaluation. New Directions for Program Evaluation, 30, 73-84.

Lubienski, S. T. (2002). A closer look at black-white mathematics gaps: Intersections of race and SES in NAEP achievement and instructional practices data. Journal of Negro Education, 71(4), 269-287.

Martin, D. (2007). Mathematics learning and participation in the African American context: The co-construction of identity in two intersecting realms of experience. In N. Suad Nasir \& P. Cobb (Eds.), Improving access to mathematics: Diversity and equity in the classroom (pp. 146-158). New York: Teachers College at Columbia University.

National Council for Teachers of Mathematics. (1989). Curriculum and evaluation standards for school mathematics. Reston, VA: Author.

National Council for Teachers of Mathematics. (2000). The principles and standards for school mathematics. Reston, VA: Author.

Newmann, F. M. (1996). Authentic achievement: Restructuring schools for intellectual quality. San Francisco, CA: Jossey-Bass.

Newmann, F. M., King, M. B., and Rigdon, M. (1997). Accountability and school performance: Implications from restructuring schools. Harvard Educational Review, 67(1), 41-69.

Newmann, F. M., King, M. B., \& Youngs, P. (2001). Professional development that addresses school capacity: Lessons from urban elementary schools. American Journal of Education, 108, 259-299.

No Child Left Behind Act, 20 U.S.C. § 6310 et seq. (2001).

Noddings, N. (2006). Educational leaders as caring teachers. School leadership and management, 26(4), 339-345. 
Patton, M. Q. (2002). Qualitative research and evaluation methods ( $3^{\text {rd }}$ ed.). Thousand Oaks, CA: Sage Publications.

Rallis, S., \& MacMullen, M. (2000). Inquiry-minded schools: Opening door for accountability. Phi Delta Kappan, 78(9), 766-773.

Remillard, J. (2005). Examining key concepts in research on teachers' use of mathematics curricula. Review of Educational Research, 75(2), 211-246.

Resnick, L. (Ed.). (2006). Do the math: Cognitive demand makes a difference. Research Points, 4(2). Washington, DC: American Educational Research Association.

Roderick, M., Jacob, B., \& Bryk, A. (2002). The impact of high-stakes testing in Chicago on student achievement in the promotional gate grades. Educational Evaluation and Policy Analysis, 333-357.

Secada, W. G. (1992). Race, ethnicity, social class, language, and achievement in mathematics. In D.A. Grouws (Ed.), Handbook of research on mathematics teaching and learning (pp. 623-659). Reston, VA: National Council of Teachers of Mathematics.

Sleeter, C. E. (2008). Equity, democracy, and neoliberal assaults on teacher education. Teaching and Teacher Education, 24(8), 1947-1957.

Smylie, J. A., Lazarus, V., \& Brownlee-Conyers, J. (1996). Instructional outcomes of school-based participative decision-making. Educational Evaluation and Policy Analysis, 18(3), 181-198.

Spillane, J. (2005). Primary school leadership practice: How the subject matters. School Leadership \& Management, 25(4), 383-397.

Spillane, J. P., Halverson, R., and Diamond, J. B. (2001). Investigating school leadership practice: A distributed perspective. Educational Researcher, 30(3), 23-28.

Stake, R. E. (1995). The art of case study research. Thousand Oaks, CA: Sage Publications.

Supovitz, J. A. (2002). Developing communities of instructional practice. Teachers College Record, 104(8), 1591-1626.

Tate, W. F. (2005). Access and opportunities to learn are not accidents: Engineering mathematical progress in your school. Greensboro, NC: SERVE. 
Tschannen-Moran, M., Woolfolk, Hoy, A., \& Hoy, W. K. (1998). Teacher efficacy: Its meaning and measure. Review of Educational Research, 68(2), 202-248.

Weiss, C. H. (1998). Evaluation (2 ${ }^{\text {nd }}$ ed.). Upper Saddle River, NJ: Prentice-Hall.

About the Author

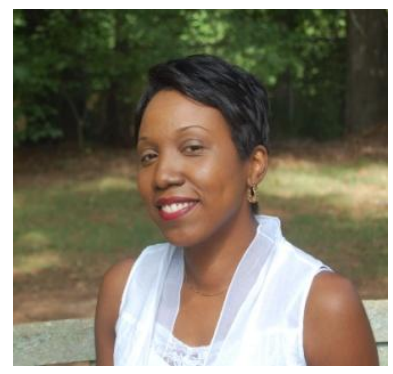

Jori N. Hall is an Assistant Professor in the Department of Lifelong Education, Administration and Policy in the College of Education at the University of Georgia. She teaches graduate courses, advancing theory and practice related to mixed methods inquiry and qualitative research. Her other work includes providing evaluative feedback for science, technology, engineering, and mathematics (STEM) educational programs. Her research interests center on the intersections of educational accountability policy and responsive evaluation approaches. Email: jorihall@uga.edu. 
Appendix $A$

\section{Interplay of the Four Collective Capacity Dimensions}

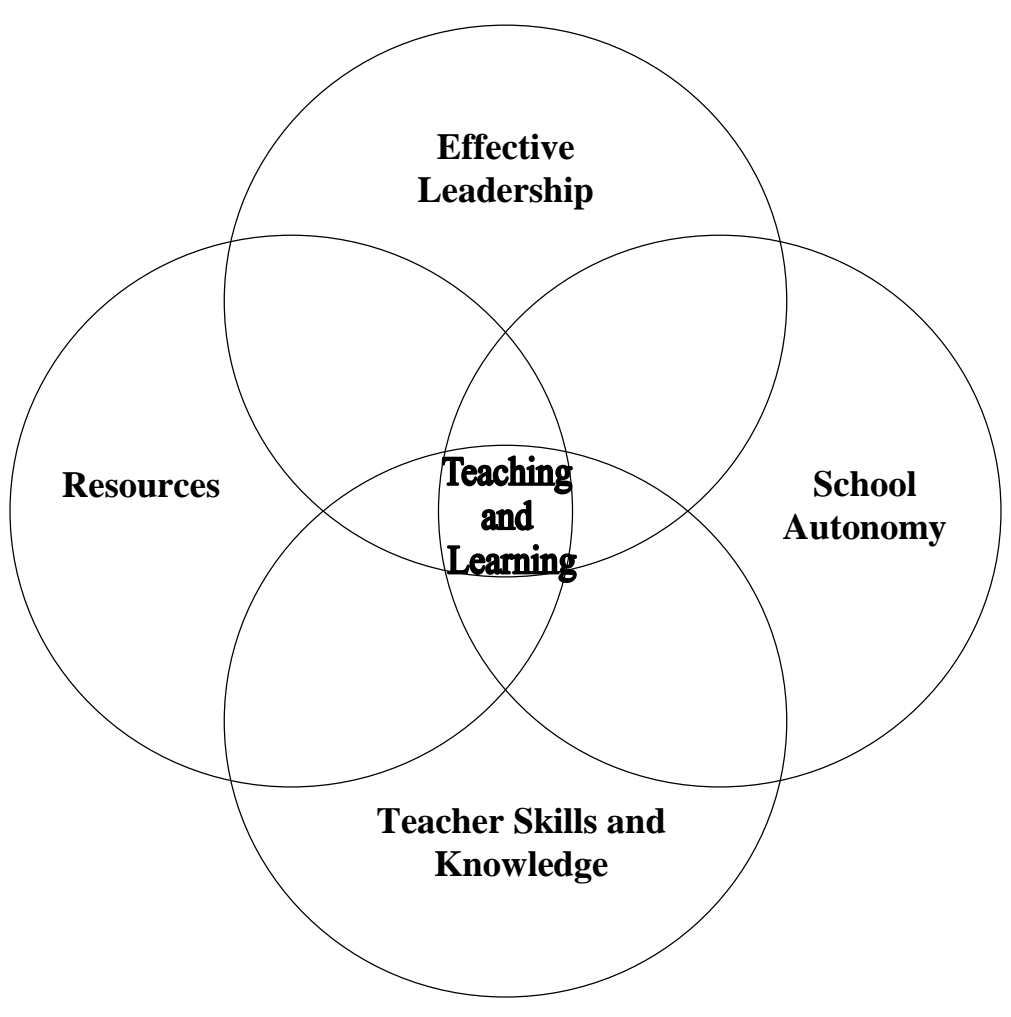

This figure displays the intended interplay of the four dimensions with the notion that each dimension is intricately interrelated and mutually reinforcing the shared and clear vision for teaching and learning. 
Appendix $B$

\section{Administrator Interview Guide}

Thank you for agreeing to participate in this interview. The interview should take approximately $20-30$ minutes. The questions are intended to understand Negola school improvement process, particularly as it relates to the math achievement of lowincome and African American learners. Specifically, I am interested in your reflections about and experiences with: (a) external accountability, (b) Negola intervention strategies, and (c) your school context.

Provided below are the questions you will be asked during the interview.

- How would you describe the school's response to external kinds of accountability (e.g., NCLB, district)?

- How would you describe the style of leadership at this school?

- Negola has initiated several interventions intended to increase the math academic achievement of student sub-groups that struggle to meet annual yearly progress (AYP), particularly the African American and low-income sub-groups. One intervention was the re-organization of faculty to teach all six math courses. Could you please describe your experiences with this re-organization?

- As an administrator, you decide how the needs of students will be addressed at Negola. Please share some of the ways you address the needs of African American and low-income students not meeting AYP goals?

- What types of resources are most important to you to meet the needs of students not meeting AYP?

- What types of challenges/successes do you face obtaining resources to meet the needs of these learners?

Thank you. 


\section{Appendix C}

\section{Collective Capacity Questionnaire}

\section{Leadership}

Administrators (e.g., principal, assistant principal, dean of students) at this school:

Collaborate with faculty and staff to make the school run effectively.

Distribute leadership tasks among other faculty and staff.

Work with faculty and staff to identify student learning goals.

Foster a collective vision for student learning goals.

Promote clear learning goals for students.

Support the modification of instructional strategies.

At this school, administrators make important decisions with input from:

Teachers.

Parents.

Students.

The community.

\section{Instruction}

This school year, with at least one other faculty or staff member, you have worked to:

Plan instruction.

Identify instructional goals.

Implement instructional strategies that target the needs of students not meeting Annual Yearly Progress (AYP).

Adjust the way you interact with students.

Adjust the way you instruct students.

Coordinate teaching with instruction at other grade levels.

Teach interdisciplinary projects.

This school year, with at least one other faculty or staff member, you have informed your instruction by reviewing:

Classroom assessment data.

School-wide assessment data.

Illinois Standards Achievement Test (ISAT) data.

Multiple forms of student data:

Collected at the school.

Continuously shared with faculty and staff at the school.

Used to inform whether learning goals for students are met.

Used to modify instruction.

The professional development experiences at this school:

Enhance my instructional practices.

Provide an opportunity for collective participation with teachers from this school.

Provide an opportunity for active learning.

Align with the learning goals set for students. 


\section{Collective Capacity Questionnaire Continued}

Align with state standards.

Deliver strategies that target the needs of students not meeting AYP goals.

\section{Decision-making}

Teachers at this school help to make decisions about:

Instructional practices.

Books and other materials used in the classroom.

Collective planning time.

Curriculum content.

Teaching assignments.

Hiring decisions.

Student learning goals.

Financial resources.

\section{Resources}

This school capitalizes on using time to work collectively to support learning goals.

Student learning goals are supported instructional materials.

When necessary, this school provides teachers with instructional support.

When necessary, this school provides teachers with additional technology training.

This school capitalizes on using students as a resource to support learning goals.

This school capitalizes on using parents as a resource to support learning goals.

This school capitalizes on using the local community as a resource to support learning goals.

Student learning goals are supported by financial resources. 
Appendix D

\section{Meeting Observation Guide}

The purpose of these observations will be to further understand and document the role of external and internal accountability in this context, with particular attention to how the four dimensions of collective capacity - school autonomy, professional skills and knowledge, resources, and leadership_ are surfaced and discussed.

The documentation will include:

a. An account of main issues or themes

b. A summary of information obtained

c. Other relevant issues that surface during the meeting

d. Questions that emerge from the meeting

e. Who talked and who didn't talk

f. Instances of leadership

g. Instances of autonomy

h. Instances of resource usage/allocation

i. Instances of professional skills and knowledge 
Appendix $E$

\section{Math Class Observation Guide}

The purposes of the mathematics class observations are to:

1. Document a descriptive record of the structure, content, and activities of the classes.

2. Capture the character of the learners' participation in the classes, paying particular attention to: (a) the level and character of the learners' engagement; (b) interactions with the teacher, each other, and materials; and (c) any other relevant events or reactions that occur in the classroom.

Description of context, setting:

1. Describe the setting of the class: physical features, people arrangement, and the general climate.

Descriptive account of math classes: The description should include the following information about key classroom activities:

1. Activity start and end time, so the records indicate how long each one took.

2. Activity goal or objective (if available).

3. Instructional method/materials (e.g., demonstrations, power point presentations, lectures, observations, hands-on activities, discussion, games, and/or paperpencil tasks).

4. Learners' engagement with instructor and materials. In a few sentences, describe engagement, enthusiasm, as well as boredom, disinterest, frustration.

5. Instructor's engagement with learners. Again, in a few sentences to describe how the instructor interacts with the students.

6. If there is an unexpected event or response that occurs during class, this should be noted as well. 


\section{Appendix $F$}

\section{Math Teacher Interview Guide}

Thank you for agreeing to participate in this interview. The interview should take approximately $20-30$ minutes. The questions are intended to understand Negola's school improvement process, particularly as it relates to the math achievement of lowincome and African American learners. Specifically, I am interested in your reflections about and experiences with: (a) external accountability, (b) Negola's intervention strategies, and (c) your classroom context.

Provided below are the questions you will be asked during the interview.

- How would you describe the school's response to external kinds of accountability (e.g., NCLB, district)?

- How would you describe the style of leadership at this school?

- Negola has initiated several interventions intended to increase the math academic achievement of student sub-groups that struggle to meet annual yearly progress (AYP), particularly the African American and low-income sub-groups. One intervention was the re-organization of faculty to teach all six math courses. Could you please describe your experiences with this re-organization?

- As a professional, you decide how the needs of students will be addressed in your classroom. Please share some of the ways you address the needs of African American and low-income not meeting AYP goals in your math class?

- What types of resources are most important to you to meet the needs of student not meeting AYP, particularly African American and low-income students in your math class?

- What types of challenges/successes do you face obtaining resources to meet the needs of these learners?

Thank you. 


\section{Appendix $G$}

\section{NMS Internal Accountability}

\begin{tabular}{ll}
\hline Aspect of internal accountability & NMS accountability strategy \\
\hline Modifying content and instruction & $\begin{array}{l}\text { Reorganization of teachers (E/I) } \\
\text { Academic support (E) } \\
\text { Professional development (E) }\end{array}$ \\
Monitoring progress & $\begin{array}{l}\text { State assessments (E) } \\
\text { Benchmark assessments (E) } \\
\text { Quarterly assessments (E) } \\
\text { Informal assessments (E/I) } \\
\text { Discipline data (E) }\end{array}$ \\
Rewards and sanctions & $\begin{array}{l}\text { Professional pressure (I) } \\
\text { Celebrations (I) }\end{array}$ \\
Social curriculum & Positive school environment (I) \\
\hline
\end{tabular}

Note. This table is adapted from Newmann et al.'s (1997) discussion of internal accountability. Letters enclosed in parentheses represent whether the method is externally - mandated $(E)$, internally - generated $(I)$, or a combination (E/I). 